\title{
AMNESTI PAJAK: SEJARAH DAN EFEKTIVITAS DI BERBAGAI NEGARA
}

\author{
Oleh: \\ Sarlina Sari \\ Mahasiswa Fakultas Ekonomi dan Bisnis \\ Program Pascasarjana Ilmu Ekonomi \\ Universitas Indonesia \\ Email: \\ sarisarlina@gmail.com
}

\begin{abstract}
ABSTRAK
Studi ini merupakan studi kualitatif deskriptif (telaah literatur) yang bertujuan untuk menganalisis sejarah dan efektivitas amnesti pajak di berbagai negara dan membandingkannya dengan konteks Indonesia. Hasil studi ini menunjukkan bahwa keberhasilan dari program amnesti pajak di berbagai negara bervariasi. Ada yang tergolong sukses seperti di Irlandia tahun 1988-1993, New York, California, Illinois, dan Michigan, dan ada juga yang belum terlalu efektif seperti Dakota Utara, Idaho, Texas, Kansas, dan Missouri. Hasil studi ini juga menunjukkan bahwa dampak program amnesti pajak terhadap peningkatan penerimaan negara transisi masih belum signifikan. Adapun di Indonesia, program amnesti pajak baru saja diberlakukan sehingga dampak program amnesti pajak terhadap peningkatan penerimaan negara Indonesia belum dapat disimpulkan.
\end{abstract}

Kata Kunci: Amnesti Pajak, Efektivitas Amnesti Pajak, Penerimaan Negara

\section{A. PENDAHULUAN}

Banyak negara menghadapi kemajuan dan keterlambatan tingkat ekonomi, sosial, keuangan dan sistem pajak yang berbeda. Deviasi fenomena dari beberapa kegiatan dari lingkaran otoritas publik resmi terhadap jaringan yang tersembunyi, di mana tidak tunduk pada organisasi publik dan hukum perburuhan serta tidak mendeklarasikan aset mereka kepada otoritas pajak. Fenomena ini dikenal sebagai "shadow economy". Pemerintah di banyak negara telah mengadopsi sejumlah langkah untuk menghadapi fenomena ini melalui beberapa metode sebagai proses kontrol dan menyebarkan kesadaran, hukuman serta memberikan insentif untuk mengubah dari shadow economy ke dalam ekonomi formal. Namun, metode yang digunakan mungkin tidak memadai untuk mengontrol fenomena ini dan melawan penggelapan pajak yang dianggap lahir dari fenomena ini. Pemerintah dapat meresort langkah-langkah lain yang mungkin lebih efektif dalam memerangi penggelapan pajak dan menyesuaikan shadow economy serta mengumpulkan pajak yang tidak tertagih sebelumnya dengan menerapkan program amnesti pajak. 
Amnesti pajak adalah program pemerintah untuk memungkinkan warga negara secara sukarela membayar pajak mereka yang sebelumnya terutang tanpa exposure penalty. Sekilas tentang sejarah keuangan pemerintah di seluruh dunia mencatat bahwa sebagian besar pemerintah memperkenalkan program amnesti pajak untuk memerangi penggelapan pajak dan menyesuaikan shadow economy serta meningkatkan penerimaan pajak dalam jangka pendek dan memperluas basis pajak dalam jangka panjang (Mouloud, 2015 ).

Amnesti pajak pertama didokumentasikan lebih dari dua ribu tahun yang lalu, dapat ditemukan pada Rosetta Stone (200 SM) di Mesir (itu dilakukan untuk pembebasan dari penjara wajib pajak). Popularitas program amnesti pajak dari waktu ke waktu menjadi semakin dimengerti di seluruh negara. Sebegitu sering, program amnesti pajak yang "sangat sukses" terjadi dan menarik media luas dan perhatian pembuat kebijakan. Salah satu contoh terbaru tersebut adalah Scudo Fiscale Italia (2001), yang menargetkan pendeklarasian modal lepas pantai dan memungkinkan pemulangan sebesar $€ 60$ miliar. Karena melibatkan jumlah yang besar, varian program amnesti ini segera muncul di beberapa negara Eropa dan negara aksesi. Di Amerika Serikat, lonjakan program amnesti pajak di beberapa negara terjadi pada akhir 1990-an dan awal 2000-an karena berkurangnya pendapatan fiskal dan keterbatasan saldo anggaran wajib.

Para pembuat kebijakan sering melihat program amnesti pajak sebagai alat kebijakan yang efisien yang menghasilkan baik manfaat jangka pendek maupun jangka menengah. Dalam jangka pendek, amnesti pajak menjadi sumber pendapatan tambahan. Pendapatan kotor dikumpulkan melalui amnesti bisa berjumlah beberapa persen dari pemungutan pajak yang ditargetkan, dan dalam beberapa kasus dapat menjadi signifikan. "Ekstra" pendapatan ini mungkin paling diinginkan di masa resesi atau krisis keuangan saat pendapatan berada di bawah tekanan dan pengeluaran tumbuh dengan cepat. Dalam jangka menengah, program amnesti pajak yang sukses diharapkan dapat meningkatkan basis pajak dan pengumpulan pendapatan di masa mendatang, seiring wajib pajak dibawa ke gawang pajak. Dengan kata lain, amnesti pajak diharapkan dapat meningkatkan kepatuhan pajak.

Dengan segera menaikkan hasil pajak yang diberikan tanpa mengubah struktur (yaitu, tarif pajak dan basis), program amnesti pajak merupakan langkah kebijakan yang efisien, dan juga salah satu yang adil, karena pendapatan yang dikumpulkan dari wajib pajak mengurangi disparitas tarif pajak efektif dari warga yang sebelumnya menghindarinya dan wajib pajak yang taat hukum. Hal ini diharapkan dapat meningkatkan ekuitas horisontal karena untuk tingkat pendapatan tertentu, seorang wajib pajak yang memiliki effective tax rate yang lebih rendah, juga berpotensi, ekuitas vertikal dalam kasus di mana motif penghindaran pajak dan peluang peningkatan fungsi pendapatan. Akhirnya, beberapa program amnesti pajak dirancang dalam pemikiran dengan tujuan ekonomi makro yang lebih luas, seperti memulangkan flight capital (untuk alasan yang melampaui pendapatan langsung dan motif kepatuhan pajak, seperti neraca pembayaran, investasi domestik, atau pertimbangan sistem keuangan). 


\section{B. METODE PENELITIAN}

Studi ini merupakan studi kualitatif deskriptif (telaah literatur) yang bertujuan untuk menganalisis sejarah dan efektivitas amnesti pajak di berbagai negara dan membandingkannya dengan konteks Indonesia.

\section{HASIL DAN PEMBAHASAN}

\section{Definisi Amnesti Pajak}

Amnesti pajak didefinisikan sebagai penetapan prosedur yang bertujuan untuk menghapus penundaan dan penyimpangan pajak, yang dengan demikian meliputi induksi pembayar pajak untuk sukarela patuh dalam sistem pajak tanpa exposure sebelumnya untuk mendapatkan dana kembali, dan biasanya digunakan amnesti pajak sebagai alat tidak langsung untuk melawan penggelapan pajak dan menyesuaikan shadow economy (Barilari dan Drape, 1992). Dalam definisi yang di-submite oleh ekonom Andreoni baru-baru ini, amnesti pajak didefinisikan sebagai: "Serangkaian langkah-langkah pemerintah untuk mengampuni semua atau sebagian dari hukuman yang ada pada wajib pajak jika mereka secara sukarela menyatakan nilai dari pendapatan yang tidak dideklarasikan dan diinvestasikan dalam shadow economy"(Chatagny, 2006).

Pemerintah dari segala jenis telah sering dan semakin beralih ke amnesti pajak sebagai bagian dari program fiskal mereka. Amnesti biasanya memberikan individu kesempatan untuk membayar pajak sebelumnya yang belum dibayar tanpa dikenakan hukuman dan penuntutan seperti yang biasanya dilakukan dalam penemuan penggelapan. Beberapa negara telah menghasilkan sejumlah besar pendapatan dengan amnesti mereka; New York mengumpulkan \$ 401 juta, California, Illinois, dan Michigan memperoleh lebih dari \$ 100 juta. Negaranegara lain yang amnesti pajaknya belum berhasil antara lain Dakota Utara, Idaho, Texas, Kansas, dan Missouri masing-masing mengumpulkan kurang dari \$ 1 juta (Alm, McKee, \& Beck, 1990).

Hal yang sama juga dijelaskan oleh Alm, Martinez-Vazquez, \& Wallace (2009) bahwa amnesti pajak biasanya memungkinkan individu atau perusahaan untuk membayar tunggakan pajak tanpa tunduk pada beberapa atau semua hukuman keuangan dan kriminal yang biasanya ditemukan dalam penggelapan pajak. Amnesti juga sering disertai dengan peningkatan upaya administrasi pajak, terutama dalam langkah-langkah penegakan (misalnya, tarif pemeriksaan yang lebih tinggi, peningkatan prosedur seleksi audit, dan hukuman yang lebih besar). Dalam dua puluh tahun terakhir, hampir empat puluh negara bagian di Amerika Serikat telah diberlakukan beberapa bentuk amnesti pajak, kadang-kadang lebih dari sekali, dan banyak negara lain di hampir semua bagian dunia telah menggunakan satu atau lebih amnesti pajak.

Dalam konteks Indonesia, amnesti pajak merupakan pengabaian pajak, sanksi administrasi, dan sanksi pidana pajak yang dapat diberikan dengan membayar Redemption Money (Uang Tebusan) sebagaimana diatur dalam undang-undang. Amnesti Pajak diberikan pada kewajiban pajak yang belum dibayar atau dilunasi oleh wajib pajak sampai dengan tahun fiskal terbaru (yang 
berakhir dalam waktu 1 Januari-31 Desember 2015) melalui aset yang dideklarasikan menggunakan Surat Pernyataan Harta untuk Pengampunan Pajak/SPHPP). Ruang lingkup amnesti pajak ini meliputi Pajak Penghasilan, Pajak Pertambahan Nilai (PPN) dan pajak penjualan mewah-barang (PPnBm) (Tax Flash, 2016).

\section{Tujuan Program Amnesti Pajak}

\section{Menyesuaikan "shadow economy"}

Tujuan negara dari pemberlakuan amnesti pajak adalah menginvestasikan kembali modal yang diinvestasikan dalam shadow economy ke dalam ekonomi formal. Selain itu, untuk pemulihan modal yang diinvestasikan di luar negeri dan kemudian diinvestasikan ke dalam negeri, yang mengarah untuk meningkatkan ukuran investasi lokal serta penerimaan negara dan meningkatkan tingkat pertumbuhan ekonomi (Rynders, 2003). Amnesti pajak bisa efektif dalam mencapai tujuan ini jika pengembalian modal dalam perekonomian formal lebih besar dari yield investigator dalam shadow economy, yang berperan untuk menarik investor yang telah menginvestasikan uang mereka dalam shadow economy menjadi diinvestasikan kembali dalam perekonomian formal, di mana investor dapat menyatakan aset mereka untuk mengambil keuntungan dari performa yang hebat dari ekonomi formal yang menyebabkan peningkatan tingkat pertumbuhan (Chatagny, 2006).

\section{Meningkatkan Penerimaan Pajak Bagi Negara}

Tujuan utama dari amnesti pajak yang disebut oleh semua ekonom adalah kesediaan pemerintah untuk meningkatkan penerimaan pajak khususnya dalam jangka pendek. Ekonom Hirling mengatakan bahwa dalam hal ini tujuan dari amnesti pajak adalah pengumpulan pendapatan yang masih di luar lingkup sistem pajak. Dalam jangka panjang, amnesti pajak memungkinkan meningkatkan penerimaan pajak di masa depan dengan memungkinkan ekspansi horizontal dari sistem pajak. Selain itu, amnesti pajak merupakan kontrol yang lebih baik di masa depan pada wajib pajak (Chatagny 2006).

\section{Dampak Amnesti Pajak terhadap Pendapatan Negara}

Amnesti pajak adalah alat peningkatan pendapatan yang kontroversial. Advokat menekankan dampak pendapatan langsung dan jangka pendek, dan sering berpendapat bahwa penerimaan pajak di masa depan dapat meningkat jika amnesti menginduksi individu atau perusahaan tidak berada dalam daftar pajak untuk berpartisipasi, dan jika amnesti disertai dengan layanan wajib pajak yang lebih luas, pendidikan yang lebih baik dalam tanggung jawab wajib pajak, hukuman pasca-amnesti yang ketat bagi penghindar pajak dan pengeluaran yang lebih besar untuk penegakan hukum. Kritikus berpendapat bahwa pengalaman nyata dari banyak negara menunjukkan bahwa dampak langsung pada pendapatan hampir selalu cukup kecil. Mereka juga mempertanyakan dampak pendapatan jangka panjang dari amnesti pajak, terutama jika pembayar pajak yang jujur 
membenci perlakuan khusus untuk penghindar pajak dan jika individu mempercayai bahwa amnesti bukan hanya kesempatan satu kali.

Hubungan antara amnesti dan pendapatan telah diuji secara empiris, namun bukti yang ada sebagian besar untuk amnesti yang diberikan oleh pemerintah negara bagian di Amerika Serikat (Fisher, Goddeeris, dan Young, 1989; Alm dan Beck, 1990; Alm, McKee, dan Beck, 1990; Dubin , Graetz, dan Wilde, 1992; Alm dan Beck, 1993; Luitel dan Sobel, 2007). Jauh lebih sedikit yang diketahui tentang dampak dari amnesti di tingkat internasional, dan lebih khususnya tentang amnesti di negara-negara transisi (Torgler, Schaltegger, dan Schaffner, 2003). Dalam amnesti pajak di Rusia, seperti kebanyakan amnesti lainnya, tampaknya tidak mungkin untuk memiliki signifikansi dan dapat dibuktikan dampak positif atau negatif pada pendapatan dari Federasi Rusia, sebuah kesimpulan yang menimbulkan pertanyaan terhadap kegunaan amnesti pajak sebagai instrumen kebijakan (Alm, Martinez-Vazquez, Wallace, 2009).

\section{Pengalaman Internasional}

\section{Pengalaman Belgia}

Dengan tujuan untuk menarik flight capital dan dana pasar gelap untuk membawa kembali ke ekonomi reguler, Belgia memberlakukan amnesti pajak pada tahun 1984. Amnesti itu membebaskan modal tersebut dari pajak jika modal itu diinvestasikan dalam kegiatan employment-generating sebelum akhir tahun 1984. Amnesti pajak juga membebaskan kewajiban untuk melaporkan asal dana, asalkan 1-12 atau 9 persen dari jumlah tersebut harus diinvestasikan dalam sertifikat treasurynon-interest-bearing selama lima tahun. Namun, kemudian pemerintah menghadapi sejumlah masalah politik pada tahun 1985, dan dipaksa untuk membatalkan undang-undang amnesti ini (Luitel, 2005).

Sejak kedatangan koalisi pemerintah antara Sosialis dan Liberal Mei 2003 ide dari penerbitan amnesti itu muncul untuk mendukung pertumbuhan melalui pemulihan modal dan investasi di sektor ekonomi informal, dan dinyatakan tujuan amnesti adalah penciptaan 200.000 lapangan pekerjaan dan prospek dari mengumpulkan pendapatan tambahan untuk membiayai kebijakan operasi. Amnesti ini disebut Deklarasi Libératoire Unique (DLU) (Mouloud, 2015).

\section{Pengalaman Irlandia}

Literatur ekonomi menawarkan pengalaman Irlandia tahun 1988 sebagai contoh program amnesti pajak yang sukses selama periode tahun delapan puluhan. Pada Januari 1988 pemerintah Irlandia memperkenalkan program amnesti pajak untuk 10 bulan bagi wajib pajak untuk membayar pajak yang belum dibayar tanpa exposure hukuman dan tanpa harus membayar denda, ekuivalen, pemerintah telah mengembangkan serangkaian tindakan yang bertujuan mendukung kemampuan pemerintah untuk mendeteksi kasus penipuan, dan meningkatkan jumlah observers yang bertugas mengumpulkan pajak. Pada akhir periode amnesti (10 bulan), pemerintah meningkatkan denda dan hukuman pajak yang terutang atas yang tidak dideklarasikan dan memberikan izin lebih luas untuk pemeriksa pajak dan memberikan mereka hak untuk cadangan aset dan juga hak untuk 
membekukan rekening bank milik wajib pajak yang telah dihukum karena penggelapan pajak (Alm, 1998).

Hasil amnesti ini lebih dari yang diharapkan. Pemerintah memperkirakan pertumbuhan penerimaan pajak sebanyak US \$50 juta. Amnesti pajak memperbolehkan pada tahun 1988 untuk mengumpulkan \$ 750 juta pajak pendapatan tambahan sebagai akibat dari transformasi shadow economy dalam ekonomi formal, yang mewakili 2,55\% dari GNP 1988, yang memungkinkan pemerintah untuk mengurangi utang 10\% dari GNP untuk tahun 1987 ke 3,4\% dari GNP untuk tahun 1988, sehingga amnesti pajak di Irlandia diizinkan untuk memperluas basis pajak pada jangka panjang (Chatagny, 2006).

Ada beberapa faktor yang membantu dalam kinerja amnesti pajak ini. Faktor utama adalah bahwa tidak ada pemerintah Irlandia sebelum 1988 yang memberlakukan amnesti pajak. Pemerintah meminta banyak warga untuk memanfaatkan amnesti ini sebagai kesempatan yang unik sebagaimana ukuran regulasi juga memainkan peran kunci dalam keberhasilan amnesti pajak di Irlandia. Namun, menurut Uchitelle keberhasilan amnesti pajak di Irlandia bisa saja lebih besar jika disertai amnesti pemerintah untuk mengurangi tarif pajak, yang merupakan salah satu tertinggi di tingkat Eropa pada periode itu, dan hal tersebut mewakili penyebab utama penggelapan pajak di Irlandia. Pemerintah Irlandia telah 5 tahun memberlakukan amnesti pajak (1993), tetapi kesuksesannya kurang dari kesuksesan pada tahun 1988, dan ini menegaskan argumen "bahwa multiple use dari amnesti pajak mengarah pada kurangnya kontribusi wajib pajak untuk setiap amnesti pajak di masa depan, yang akhirnya mengurangi efisiensi dari amnesti pajak tersebut" (Uchitelle, 1989).

\section{Pengalaman Italia-Tax Shield (2002)}

Pemerintah Italia memberlakukan amnesti pajak dalam rangka melaksanakan program pengurangan pajak tanpa melanggar aturan fiskal yang diberlakukan oleh Uni Eropa, dan menempatkan hukum amnesti pajak umum pemerintah Berluscouni yang mulai berlaku pada bulan September 2001 hingga 25 Mei 2002. Tujuan dari amnesti pajak ini untuk mengembalikan modal yang telah ada (diinvestasikan) luar negeri ke Italia, serta deklarasi kegiatan yang tidak dideklarasikan kepada otoritas pajak di Italia. Individu dan perusahaan sebagai penerima yang paling penting dari amnesti ini harus menginvestasikan $12 \%$ dari modal yang dideklarasikan untuk jangka waktu tidak kurang dari 10 tahun.

Jika prosedur ini memungkinkan pengumpulan pendapatan tambahan, diperkirakan sebesar $€ 1,47 \mathrm{M}$ setara dengan 0,1\% dari PDB antara September 2001 dan Mei 2002. Hal itu merupakan settlement amounted sebesar $€ 58.8 \mathrm{M}$ dari modal yang diinvestasikan dalam shadow economy dan di luar negeri, yang mewakili 4,7\% dari PDB di Italia. Dan asset yang diperkirakan tidak dideklarasikan yang ditransaksikan dalam shadow economy atau keluar dari Italia sebanyak $€ 560 \mathrm{M}$ dan mewakili nilai yang telah settled sebagai hasil dari setara amnesti pajak dari $11 \%$ dari aset yang tidak dideklarasikan atau yang diinvestasikan di luar negeri (Chatagny, 2006). 


\section{Pengalaman dari Negara Transisi}

Selama dekade terakhir hampir semua negara dalam transisi melancarkan upaya reformasi pajak skala besar dengan tingkat keberhasilan yang sangat berbeda (Martinez-Vazquez dan McNab, 2000). Rendahnya kepatuhan wajib pajak (atas standar internasional) telah selalu menjadi masalah di semua negara transisi ini. Kepatuhan wajib pajak yang relatif rendah ini biasanya sudah dijelaskan sebagai warisan logis dari yang direncanakan rezim sosialis di mana pajak sering tidak secara eksplisit ada, setidaknya pada tingkat individu atau rumah tangga, di mana pembayaran yang sering dinegosiasikan, tidak ada tradisi kepatuhan sukarela, administrasi pajak sangat lemah, dan ada ketidakpercayaan publik secara luas terhadap lembaga pemerintah. Tarif penalti resmi yang tinggi memperburuk masalah kepatuhan karena pembayar pajak mengeluh bahwa, ketika mereka telat membayar pajak, mereka dengan cepat mengumpulkan denda besar dan beban bunga. Dengan pendapatan pajak yang rendah dan menurun serta kepatuhan yang rendah, tidak mengherankan bahwa negara-negara transisi ini tergoda oleh solusi potensial yang ditawarkan oleh amnesti pajak. Namun, efek dari amnesti pajak di negara transisi yang baru saja memperkenalkan amnesti pajak pada skala luas belum diketahui (Alm, Martinez-Vazquez, Wallace, 2009).

\section{Analisis Efektivitas Implimentasi Amnesti Pajak di Indonesia Tahun 2016}

Aplikasi amnesti pajak di Indonesia masih merupakan kebijakan perpajakan baru yang memiliki reaksi pro dan kontra di masyarakat. Kebijakan ini pada dasarnya bertujuan untuk meningkatkan tingkat kepatuhan wajib pajak yang pada akhirnya akan meningkatkan penerimaan Negara karena diharapkan dapat mengembalikan dana yang selama ini diinvestasikan dalam shadow economy atau di luar negeri ke dalam negeri. Amnesti pajak di Indonesia diharapkan berjalan efektif sebagaimana pengalaman Negara-negara lain, namun tetntu saja harus diimbangi dengan infrastruktur dan supporting tax observers yang memadai.

Kepala Bidang Industri dan Perdagangan DPP Perindo, Hendrik K Luntungan berpendapat bahwa publik bertanya-tanya mengenai azas keadilan dan motif spekulasi di balik kebijakan amnesti pajak di Indonesia. Selain itu, menurut Hendrik penerapan kebijakan ini di Indonesia memiliki dua masalah utama. Pertama, pemerintah harus juga mempertimbangkan biaya sosial disamping menghitung target penerimaan Negara yang bisa dicapai. Kedua, selama ini pemerintah masih menjelaskan mengenai cost dan benefit dari amnesti ini dalam tataran normatif saja dan belum memastikan kepada masyarakat bahwa kebijakan ini tidak akan membuka peluang baru bagi tindakan penyelewengan uang Negara. Amnesti pajak dalam artian mengembalikan dana dari luar negeri ke dalam negeri bukan hal yang mudah dan rawan tindak koruptif, sehingga dikhawatirkan kebijakan ini merupakan sebuah scenario pengalihan isu untuk mengaburkan tindakan peminjaman utang luar negeri oleh pemerintah. 


\section{SIMPULAN}

Program amnesti pajak telah ada sejak lebih dari dua ribu tahun yang lalu di Mesir (200 SM). Namun menjadi popular di Amerika, Eropa maupun di Negara lain sejak tahun 1980-an. Amnesti pajak bertujuan untuk menarik kembali dana yang selama ini di investasikan dalam shadow economy atau di luar negeri untuk diivestasikan di dalam negeri dengan harapan untuk meningkatkan penerimaan Negara.

Studi ini merupakan studi kualitatif deskriptif (telaah literatur) yang bertujuan untuk menganalisis efektivitas amnesti pajak di berbagai negara dan membandingkannya dengan konteks Indonesia. Hasil studi ini menunjukkan bahwa keberhasilan dari program amnesti pajak di berbagai Negara bervariasi. Ada yang tergolong sukses seperti di Irlandia tahun 1988-1993, New York, California, Illinois, dan Michigan, dan ada juga yang belum terlalu efektif seperti Dakota Utara, Idaho, Texas, Kansas, dan Missouri.

Di Indonesia sendiri yang tergolong Negara transisi, kebijakan amnesti pajak baru diberlakukan di tahun 2015. Mengenai efektivitas amnesti pajak ini masih harus dikaji dari waktu ke waktu untuk mengetahui cost dan benefit dari penerapan amnesti pajak di Indonesia. 


\section{DAFTAR PUSTAKA}

Alm, J. (1998). Tax Policy Analysis: The Introduction of a Russian Tax Amnesty, Working Paper 98-6, International Studies Program, Georgia State University.

Alm, J., M. McKee, and W. Beck. (1990). Amazing Grace: Tax Amnesties and Compliance. National Tax Journal. Vol. 43, pp. 23-37.

Alm, J., Martinez-Vazquez, J., \& Wallace, S. (2009). Do Tax Amnesties Work? The Revenue Effects of Tax Amnesties During the Transition in the Russian Federation. Economic Analysis \& Policy, Vol. 39 No. 2, pp. 235-255.

Barilari, A \& Drape, R. (1992). Amnistie Fiscale Dans Le Lexique Fiscale.

Chatagny, F. (2006). Analyse Economique des Amnisties Fiscales, Travail de Master, Fribourg.

Luitel, H. S. (2005). Essays on Value Added Tax Evasion And Tax Amnesty, Doctor of Philosophy In West Virginia University.

Luitel, H.S. and R.S. Sobel. (2007). The Revenue Impact of Repeated Tax Amnesties, Public Budgeting \& Finance. Vol. 27, pp. 19-38.

Martinez-Vazquez, J. and R. McNab. (2000). The Tax Reform Experiment in Transitional Countries, National Tax Journal. Vol. 53, pp. 273-298

Mouloud, M. (2015). The Tax Amnesty Program: as Tool to Adjust the Shadow Economy; the International Experiences. Global Advanced Research Journal of Economics, Accounting and Finance, Vol. 3 (2) pp. 017-025.

Rynders, D. (2003). Amnistie Fiscale, Belgique.

Tax Flash. (2016). Tax Indonesia / June 2016 / No.9.

Torgler, B., C.A. Schaltegger, and M. Schanffner. (2003). Is Forgiveness Divine? A Cross-culture Comparison of Tax Amnesties, Schweizerische Zeitschrift fur Volkswirtschaft und Statistik. Vol. 139, pp. 375-396.

Uchitelle. (1989). The Effectiveness of Tax Amnesty Programs in Selected Countries, FRBNY Quarterly Review, autumn. 